\title{
Acute Oral Toxicity of Cincalok Oil in Wistar Rats
}

\section{Siti N.Nurbaeti ${ }^{1 *}$, Inarah Fajriaty ${ }^{1}$, Fajar Nugraha ${ }^{1}$, Hadi Kurniawan ${ }^{1}$, Winda Rahmalia², Thamrin Usman², Dwi I. Prayitno ${ }^{3}$}

\author{
${ }^{1}$ Department of Pharmacy, Medical Faculty, Tanjungpura University, West Borneo, Indonesia \\ ${ }^{2}$ Department of Chemistry, Faculty of Mathematics and Natural Science, Tanjungpura University, West Borneo, Indonesia \\ ${ }^{3}$ Department of Marine Science, Faculty of Mathematics and Natural Science, Tanjungpura University, West Borneo, \\ Indonesia
}

Submitted 16 February 2020; Revised 28 September 2020; Accepted 22 December 2020 ; Published 21 June 2021

*Corresponding author: sitinaninurbaeti@pharm.untan.ac.id

\begin{abstract}
Cincalok is a West Kalimantan traditional fermented food that has an opportunity to be developed into supplement products as a source of omega 3 and astaxanthin. This study was designed to observe the acute toxicity of Cincalok oil in female rats for its safety profile using AOT 425 program. Cincalok oil for the acute $(2000$ and $5000 \mathrm{mg} / \mathrm{kg}$ ) toxicity studies was administered orally according to the OECD guidelines 425 . The rat's body and organs weight were observed then signs of toxicity were assessed. $\mathrm{LD}_{50}$ was being determined at the end of the study. The result showed that a single dose of Cincalok oil at 2000 or $5000 \mathrm{mg} / \mathrm{kg}$ had no lethal effect, behavioral change, a significant change in rat's bodyweights, or any lesion on the rat's organs. The $\mathrm{LD}_{50}$ of Cincalok oil for oral administration was higher than $5000 \mathrm{mg} / \mathrm{kg}$ and categorized as practically non-toxic.
\end{abstract}

Keywords: Acute Toxicity, Cincalok Oil, LD ${ }_{50}$.

\section{Toksisitas Oral Akut dari Minyak Cincalok pada Tikus Wistar}

\begin{abstract}
Abstrak
Cincalok adalah makanan fermentasi tradisional Kalimantan Barat yang memiliki peluang untuk dikembangkan menjadi produk suplemen sebagai sumber omega 3 dan astaxanthin. Penelitian ini dirancang untuk mengamati toksisitas akut minyak Cincalok pada tikus betina untuk profil keamanannya menggunakan program AOT 425. Minyak Cincalok untuk studi toksisitas akut (2000 dan $5000 \mathrm{mg} /$ $\mathrm{KgBB}$ ) diberikan secara oral sesuai dengan pedoman OECD 425. Berat badan dan organ tikus diamati kemudian tanda-tanda toksisitas dinilai. $\mathrm{LD}_{50}$ ditentukan pada akhir penelitian. Hasilnya menunjukkan bahwa dosis tunggal minyak Cincalok pada 2000 atau $5000 \mathrm{mg} / \mathrm{KgBB}$ tidak memiliki efek mematikan, perubahan perilaku, perubahan berat badan tikus yang signifikan, atau lesi pada organ tikus. $\mathrm{LD}_{50}$ minyak Cincalok untuk pemberian oral lebih tinggi dari $5000 \mathrm{mg} / \mathrm{KgBB}$ dan dikategorikan sebagai praktis tidak beracun.
\end{abstract}

Kata Kunci: LD ${ }_{50}$, Minyak Cincalok, Toksisitas Akut. 


\section{Introduction}

Cincalok is a West Kalimantan traditional food made from shrimp which is fermented with microbes. ${ }^{1}$ Similar products are also known with different names, like Ronto In South Kalimantan, Cincaluk in Malaysia, Balaobalao in Philippine, Kong chai in Korea, and Kong soom in Thailand. ${ }^{2}$ Cincalok contains shrimp, salt, and sugar and it is usually consumed directly as a side dish with or without cooked. ${ }^{1}$ Cincalok has high nutritional content obtained from shrimp such as carbohydrates, protein, and fat. ${ }^{3}$ According to Khairina (2016), cincalok contains complete amino acids and fatty acids such as glutamic acid, palmitoleic acid, omega 3 , and omega $6 .^{2}$ Shrimp as one of the main components in cincalok has a high nutritional content including astaxanthin which is the main carotenoid compound in shrimp that prevent various degenerative diseases such as cancer, cataracts, and the heart due to its antioxidant activity. ${ }^{4}$ Unsaturated fatty acids (omega 3,6) are important for organs nutrient. ${ }^{5}$ Due to its beneficial ingredients, Cincalok has an opportunity to be developed into supplement products as a source of omega 3 and astaxanthin. This study was designed to find out the safety profile of Cincalok oil by acute oral toxicity study in female rats based on Organization for Economic Cooperation and Development (OECD) guideline 425. Acute oral toxicity is needed as one of the initial safety profile tests to find out the $\mathrm{LD}_{50}$ or the maximum dose that can still be tolerated by the animal subject and several signs as the toxicity symptoms that may occur to the animal subject. Therefore, the safe limit for the consumption of a substance can be obtained to avoid toxic effects. ${ }^{6,7}$

\section{Method}

\subsection{Equipment}

The equipment included surgical instruments (Aesculap M376108, USA), glassware (Iwaky pyrex, Japan), protection test equipment, blenders (Philips, Dutch), hot plates (Torrey Pines Scientific HP 10-2, USA), refrigerators (Toshiba, Japan), analytic scales (Shimadzu AUY-220, Japan), oral sonde, 1 cc syringes, mouse scales, and vacuum dryer (Maksindo VD-4, Indonesia).

\subsection{Materials}

VCO (Virgin Coconut Oil) were obtained from PT Dwi Centra Cahaya Wiguna, Pontianak, Indonesia. The Cincalok was purchased from a home industry in Singkawang City, West Kalimantan with characteristic paste form, pink color, has a mixed taste of salty and sour, and has a specific aroma of shrimp..

\subsection{Procedure}

The experimental animal protocols was authorized by the Animal Ethics Committee of Medicine Faculty, Tanjungpura University, West Kalimantan (number of ethical clearance: $\quad$ 6627/UN22.9/TA.00.03/2019). Animal subjects that used in this research were female Wistar rats (Ratus novergicus), aged 3 months, weighing 150-200 g (no weight variation more than $20 \%$ ), not pregnant, not disabled/have any physical abnormalities, and did not experience significant weight loss during acclimatization.

Wet cincalok was filtered, and the residue was dried at $50^{\circ} \mathrm{C}$ for 3 hours using a vacuum dryer. It was ground using a blender to become a fine powder. Cincalok fine powder was soaked using VCO solvent, and it was ground again for 30 minutes. The mixture was filtered after 24 hours passed.

Cincalok oil is induced in rats at a dose $2000 \mathrm{mg} / \mathrm{KgBW}$ and $5000 \mathrm{mg} / \mathrm{KgBW}$, with the use of rats in this study a maximum of 5 mice for each test. The rats were observed during the first 24 hours for the beginning of any immediate toxic signs or mortality. If there was no mortality, the experiments were continued being observed during 14 days without any dosing, to observe mortality, behavioral changes, and any acute delayed effect. The data analyzed using AOT 425 program and SPSS application with a 95\% confidence level. ${ }^{8,9}$

\section{Result}

The test animals were observed for $30 \mathrm{~min}, 60 \mathrm{~min}, 120$, and then for $24 \mathrm{~h}$ and 
continued for 14 days. The body weights of all the animals both in the dose of $2000 \mathrm{mg} /$ $\mathrm{Kg} \mathrm{BW}$ and $5000 \mathrm{mg} / \mathrm{Kg} \mathrm{BW}$ are shown in Fig. 1.

Behavioral observations for the dose of $2000 \mathrm{mg} / \mathrm{Kg}$ BW showed that all parameters were normal except the motoric and platform activities, Haffner parameter, grooming, defecation, and urination. The motoric activity decreased after being given the cincalok oil for 1 hour but increased again after 24 hours. The platform activity also decreased after being given the cincalok oil until 24 hours. The Hafner parameter decreased only after 14 days of administrations. The parameters of grooming, defecation, and urination had fluctuation results including pineal and corneal reflex, flexion induction, hanging, reestablishment, straub, piloerection, ptosis, lacrimation, catalepsy, respiratory, salivation, vocalization, tremor, convulsions, and writhing were normal during the study. The detailed observations are showed in Table 1.

Behavioral observations for the dose of $5000 \mathrm{mg} / \mathrm{Kg} \mathrm{BW}$ showed that all parameters were normal except platform activity, Hafner parameter, grooming, defecation, and urination. The platform activity decreased after being given the cincalok oil until 14 days after administration. The parameters of hafner, grooming, defecation, and urination had fluctuation results. The detailed observations are showed in Table 2.

No lesion was found on the examination of isolated vital organs such as heart, kidney, liver, lung, and spleen. The organ to body weight index was summarized in Fig. 2.

Based on the results, most of the organ index results showed the decreasing of organ index in dose $2000 \mathrm{mg} / \mathrm{kg}$ BW Cincalok oil compared to the $5000 \mathrm{mg} / \mathrm{kg} \mathrm{BW}$, except in the liver organ index. But statistically, there was no significant variation present among the groups.

The results of the limit test with dose of $2000 \mathrm{mg} / \mathrm{Kg} \mathrm{BW}$ and $5000 \mathrm{mg} / \mathrm{Kg} \mathrm{BW}$ on 5 rats exhibited no mortality. $\mathrm{LD}_{50}$ value is obtained through data processing with AOT 425 StatPgm software and showed that LD50 of Cincalok oil was higher than 5000 $\mathrm{mg} / \mathrm{kg} \mathrm{BW}$ (Fig 3 and Fig 4). According to globally harmonized classification system, cincalok oil can be put in lower toxicity class on practically non-toxic categories.

\section{Disscussion}

Cincalok has characteristics shaped like pasta, pink in color, mixed salty and sour, and a specific aroma of shrimp. ${ }^{8}$ The pink color of cincalok is presumably from the astaxanthin component which undergoes the hydrolysis and proteolysis during the

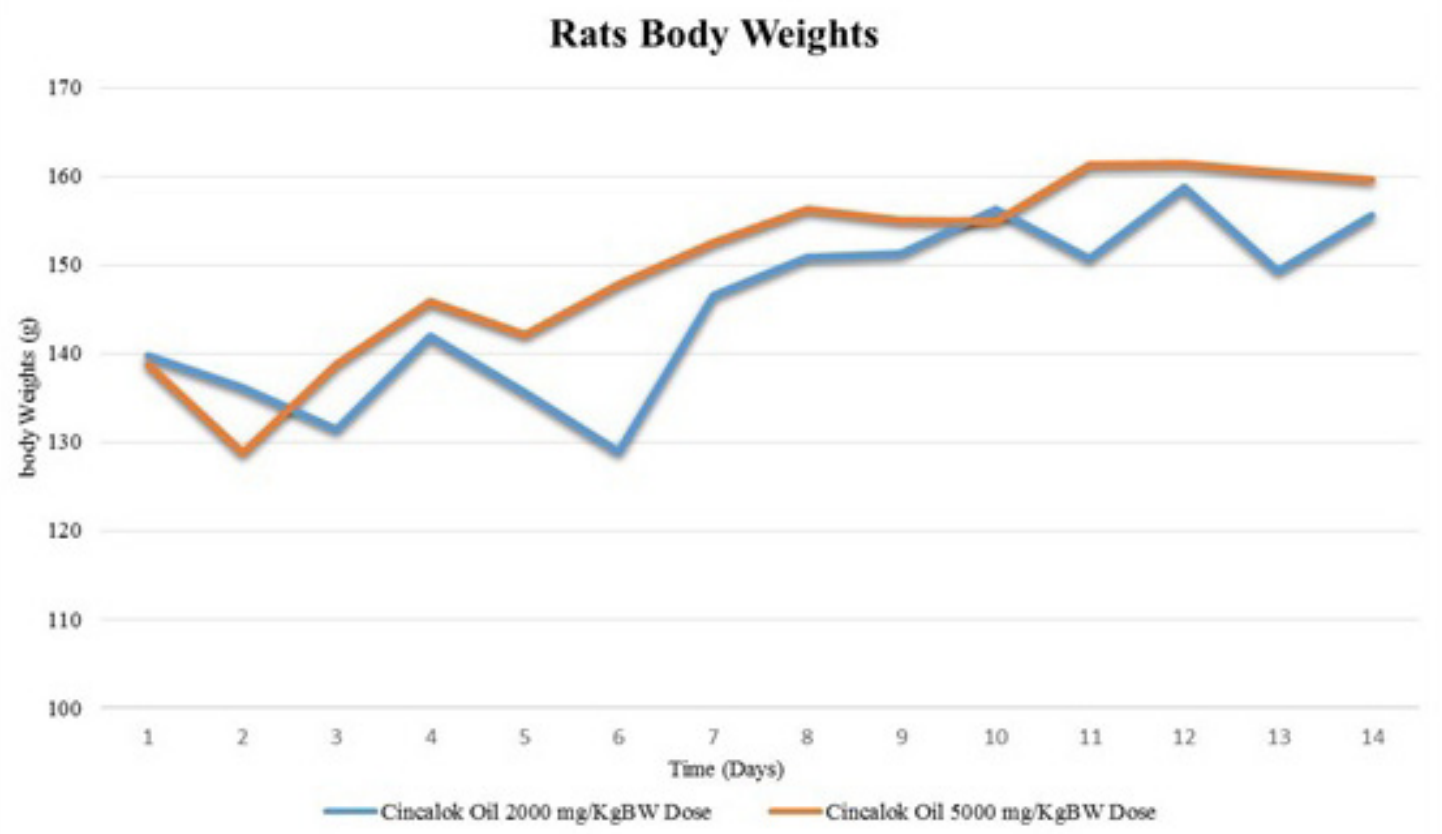

Figure 1. Effect of cincalok oil on body weight of Wistar female rats in acute toxicity studies 
Table 1. Effect of $2000 \mathrm{mg} / \mathrm{Kg} \mathrm{BW}$ cincalok oil on the behaviour of white Wistar female rats in acute toxicity studies.

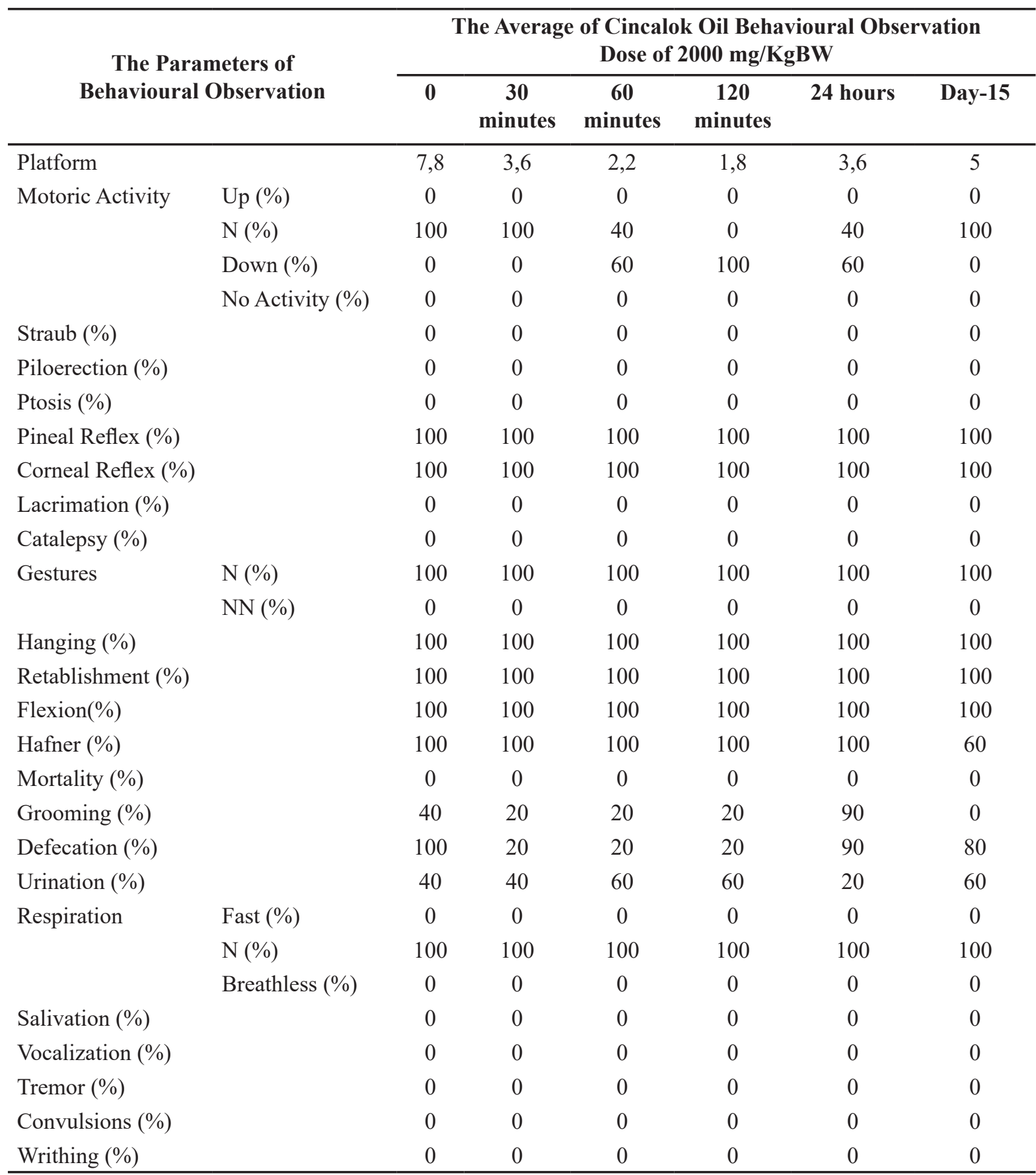

Note: $\mathrm{N}=$ Normal, $\mathrm{NN}=$ Not Normal

shrimp fermentation process. Astaxanthin is the carotenoid compound in shrimp that can prevent various degenerative diseases such as cancer, cataracts, and heart due to its antioxidant activity. ${ }^{4}$ Khairina (2016) tested Ronto (the term of Cincalok in South Kalimantan) also found the complete amino acids and fatty acids contain such as glutamic acid and polyunsaturated fatty acids (omega 3 and omega 6$){ }^{2}$ Due to the various useful compounds in it, Cincalok has the opportunity to be developed into a supplement.

Although Cincalok has been consumed as a side dish and has various benefits from its compounds, it does not mean that it is completely safe, especially if it will be developed as a medicine or supplement. Herbal ingredients are known to be safe as a medicine, nowadays they have increased in the number of reported cases of acute and 
Table 2. Effect of $5000 \mathrm{mg} / \mathrm{Kg} \mathrm{BW}$ cincalok oil on the behaviour of white Wistar female rats in acute toxicity studies.

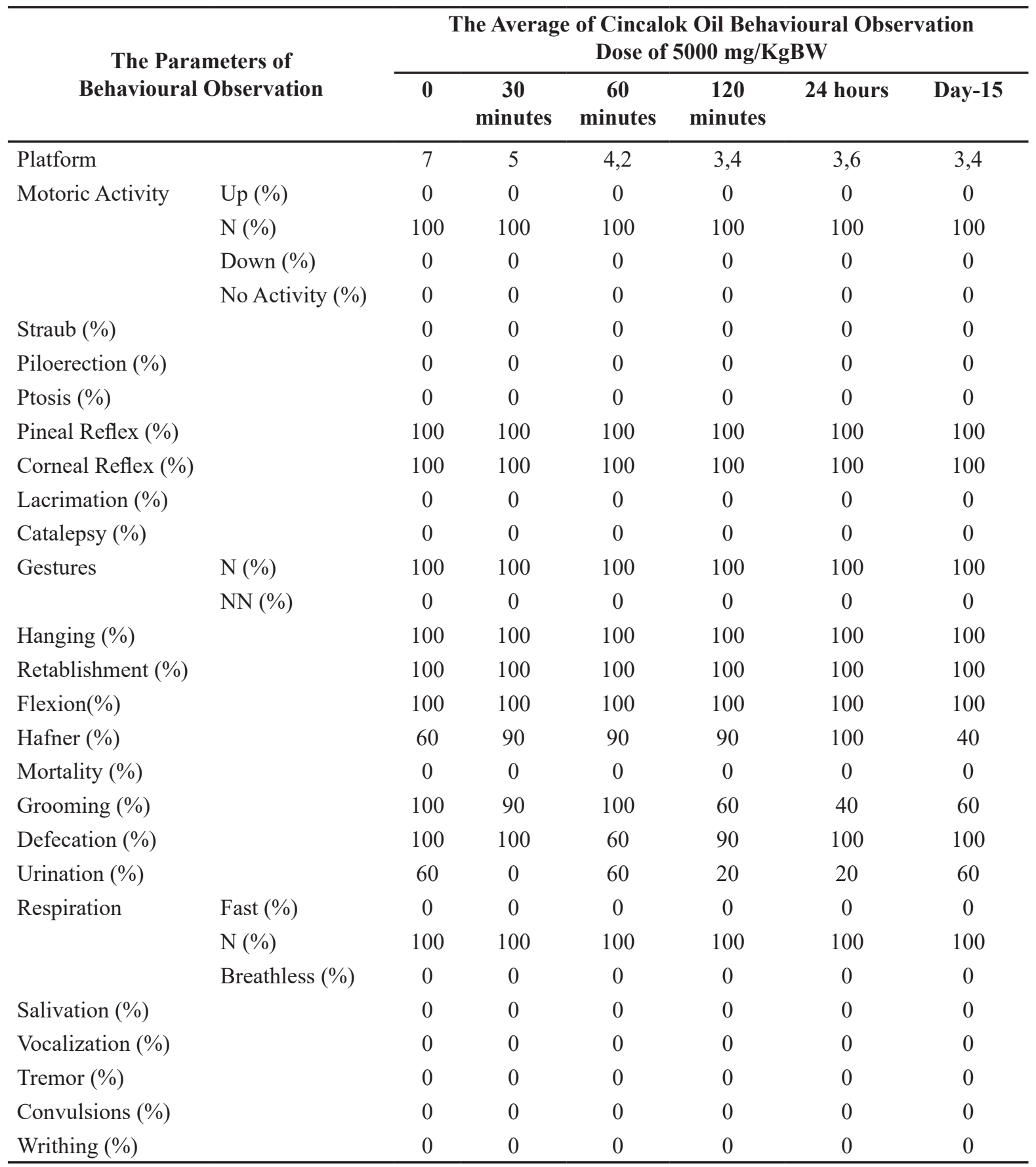

chronic poisoning due to their use. ${ }^{9}$ Shrimp as a basic ingredient in Cincalok can also have the potential to cause toxic effects due to contamination of waste in the sea such as $\mathrm{Pb}, \mathrm{Cu}$, and $\mathrm{Cd}$ that are harmful to the body. ${ }^{10}$ Therefore, toxicological evaluation is needed to know the safety of herbal medicines, which according to FDA and WHO recommendations, the validation of the effectiveness and safety of using herbal therapy can be done through scientific-based studies. Research on the safety of cincalok has never been done before, so this study was conducted to assess the acute toxicity of Cincalok oil following the Organization for Economic Cooperation and Development (OECD) 425 guideline, to determine a safe dosage range in its development as a drug. ${ }^{11,12}$ In this study, the extraction of Cincalok used an oil solvent because the compounds contained in cincalok, including astaxanthin, are oil-soluble pigments. Virgin Coconut Oil (VCO) in the research of Sindhu (2011) and Phromthong (2012) can extract 


\section{Percentage of Rats Organ Weights Index}

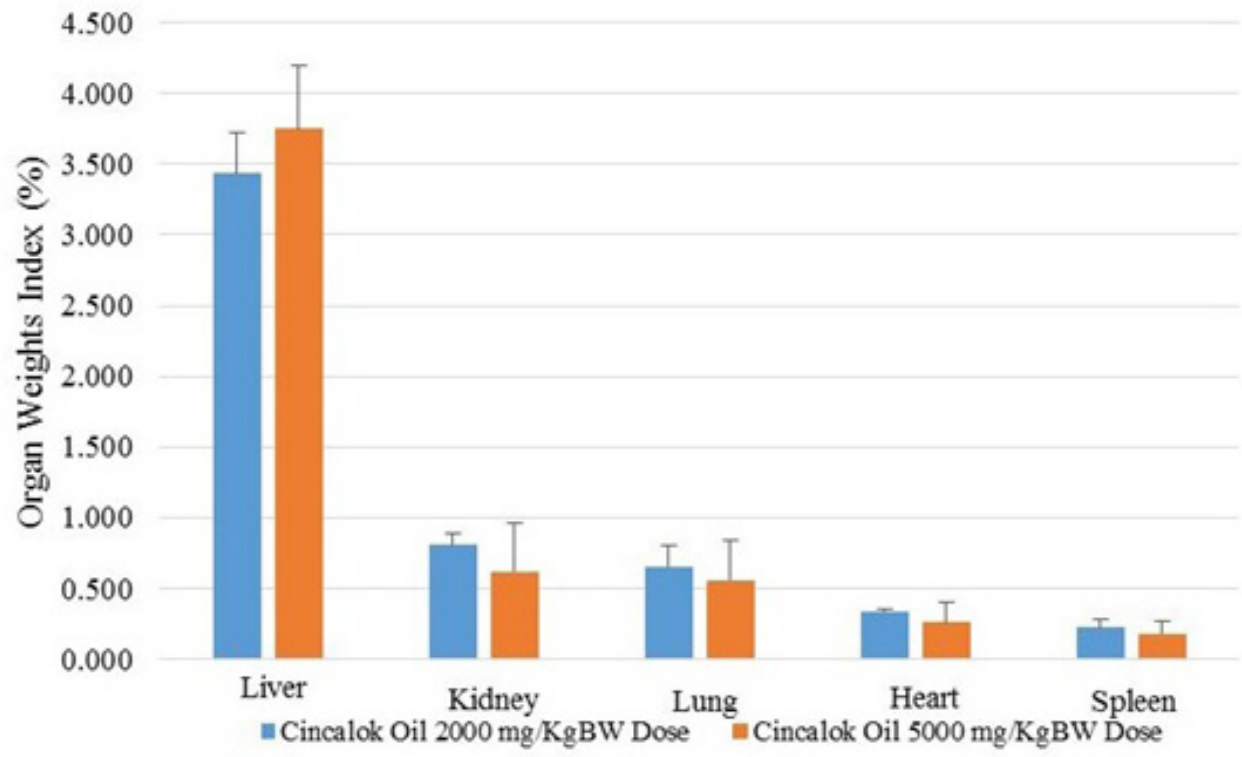

Figure 2. The percentage of organ index after being given cincalok oil.

more astaxanthin than other vegetable oil solvents, therefore VCO solvent was used to optimize the uptake of existing content. ${ }^{13,14}$ In this study, Wistar strain rats were used as the tested animals because these rats are easy to obtain and maintain, also have good growth. ${ }^{15}$ The reason for using only female rats is because male rats are more sensitive to the compound and the OECD has established guidelines that recommend that in acute oral toxicity testing. ${ }^{16}$

During 14 days of acute toxicity evaluation, no mortality was found while there were some changes in behavioral patterns like decreased motoric activity, decreased platform activity, and fluctuation of Hafner parameters, grooming, defecation, and urination. The decreased in motoric

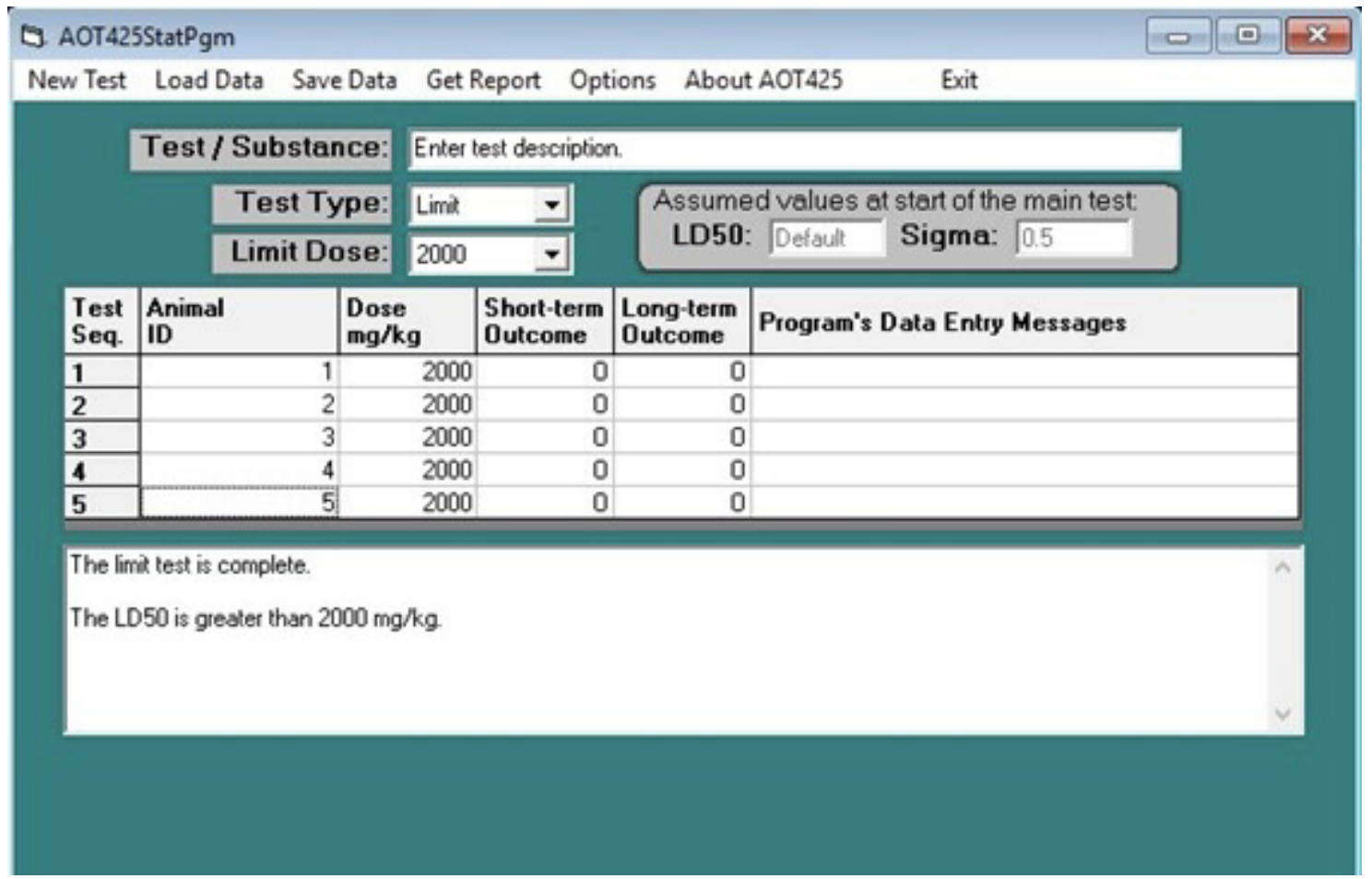

Figure 3. Acute toxicity result of cincalok on limit test of dose of $2000 \mathrm{mg} / \mathrm{kg} \mathrm{BW}$ 


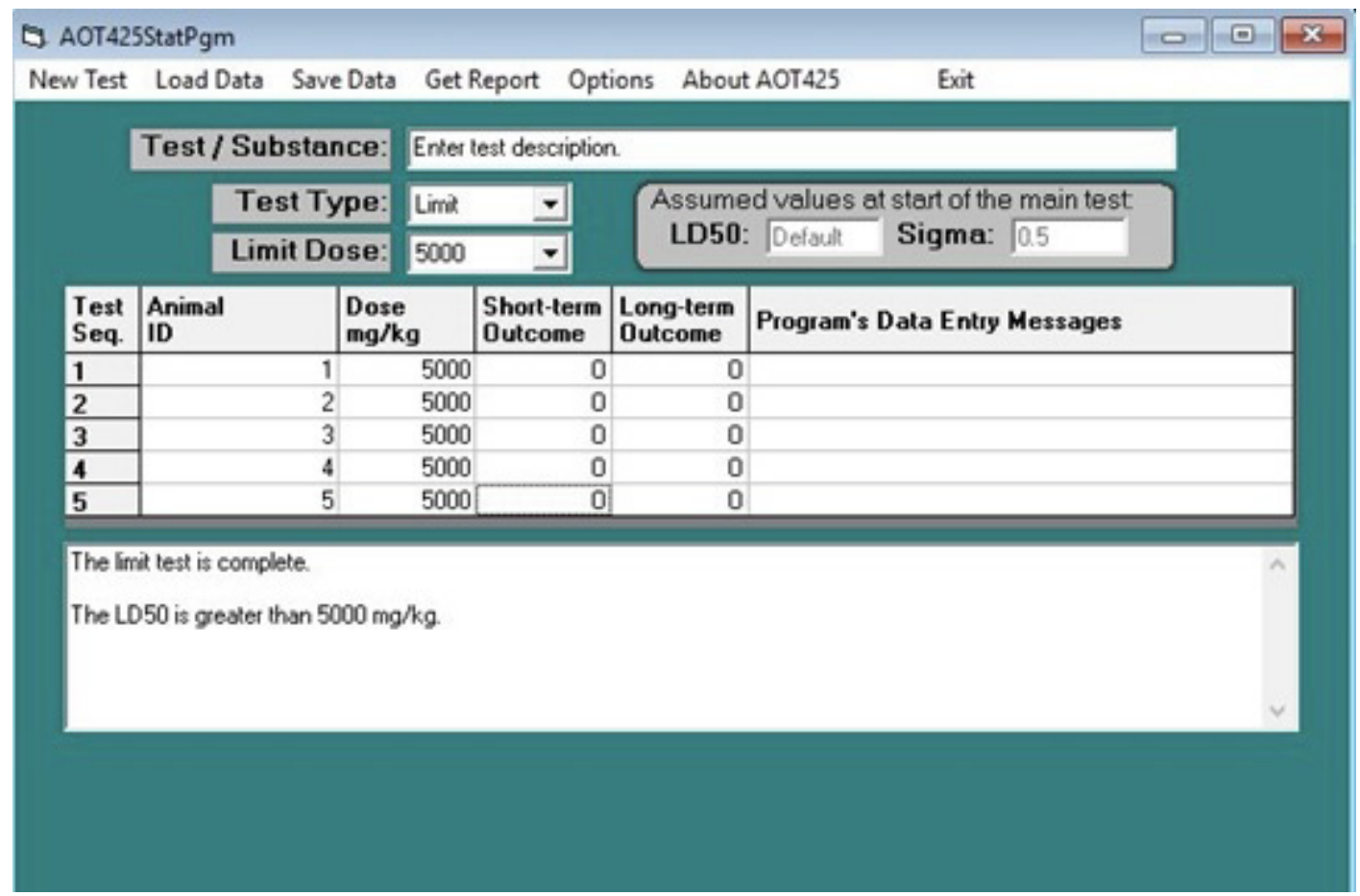

Figure 4. Acute toxicity result of cincalok on limit test of dose of $5000 \mathrm{mg} / \mathrm{kg} \mathrm{BW}$

and platform activities is a manifestation of sedative activity, muscle relaxants, paralysis, or anesthesia. The behavior parameter of Haffner, grooming, defecation, and urination is associated with fearful and stressful situations. As a conclusion, Cincalok oil can be considered affecting on nervous system because it decreased motoric and platform activities. $^{17}$

The observations of body weight showed that there were no significant body weight variations in both doses. It indicated the normal processing of carbohydrate, protein, and lipids metabolism and normal functions of vital organs in the body, which are the major targeted area of any toxic substance metabolically. ${ }^{11}$

There were no lesions found on macroscopic examination of the heart, kidney, liver, lung, and spleen. Statistically, no significant variations were found in organ to body weight index of rats. $\mathrm{LD}_{50}$ value was obtained through data processing with AOT 425 StatPgm software and showed that $\mathrm{LD}_{50}$ of Cincalok oil was higher than $5000 \mathrm{mg} /$ $\mathrm{kg}$ BW. According to a globally harmonized classification system, Cincalok oil can be put in a lower toxicity class on practically non-toxic categories. ${ }^{18}$ If we see from the toxicity of the individual components, these results are appropriate because of the astaxanthin obtained from P. carotinifaciens has no significant observed side effects when observed in mice wat dose levels much higher than the levels currently used by the supplement industry. ${ }^{19}$ Another result for astaxanthin from Haematococcus pluvialis in pregnant rats is the $\mathrm{LD}_{50}$ reaching a value greater than $20 \mathrm{~g} / \mathrm{kg}^{20}$

\section{Conclussion}

The cincalok oil has an $\mathrm{LD}_{50}$ greater than $5000 \mathrm{mg} / \mathrm{kg}$ BW which is categorized as practically non-toxic. However, the preliminary results suggested that it should be further evaluated for long term use and repeated dose effects to ensure the safety of cincalok oil.

\section{Acknowledgments}

Thanks to Tanjungpura University who have funded this research, and to the Clinical and Pharmacology Laboratory, Faculty of Pharmacy, Tanjungpura University.

\section{References}

1. R. Nofiani and A. Puji. Physicochemical and Microbiological Profiles of 
Commercial Cincalok from West Kalimantan. JPHPI. 2018; 21, 243-249.

2. R. Khairina, Y. Fitrial, H. Satrio, and N. Rahmi. Physical, Chemical, and Microbiological Properties of 'Ronto' a Traditional Fermented Shrimp from South Borneo, Indonesia. Aquat. Procedia. 2016; 7, 214-220.

3. W. Syarif, R. Holinesti, A. Faridah, and L. Fridayati. Analisis Kualitas Sala Udang Rebon. J. Teknol. Pertan. Andalas. 2017; 21, 45-51.

4. S. Chintong, W. Phatvej, U. Rerk-Am, Y. Waiprib, and W. Klaypradit. In vitro antioxidant, antityrosinase, and cytotoxic activities of astaxanthin from shrimp waste," Antioxidants. 2019; 8, 1-11.

5. J. Ngginak, H. Semangun, J. C. Mangimbulude, and F. S. Rondonuwu. Komponen Senyawa Aktif pada Udang Serta Aplikasinya dalam Pangan. J. Sains Med. 2013; 5, 128-145.

6. N. Anzini, I. Kusharyanti, and S. N. Nurbaeti. Uji Toksisitas Akut Fraksi Etil Asetat Batang dan Daun Pacar Air (Impatiens balsamina Linn) terhadap Tikus Putih Betina Galur Sprague Dawley. J. Trop. Pharm. Chem. 2014; 2, 235-247.

7. E. Nurqolbiah, I. Kusharyanti, and S. N. Nurbaeti. Uji Toksisitas Fraksi Air Impatiens balsamina Pada Tikus Betina Galur Sprague Dawley. Pharm. Sci. Res.2014; 1, 16-29.

8. K. Rita, C. Muhammad Nur, U. Tyas, and R. Sri. Karakteristik Fisikawi, Kimiawi, dan Mikrobiologis Ronto Selama Penyimpanan. JPHPI. 2016; 19, 348-355.

9. A. Aydin, G. Aktay, and E. Yesilada. A guidance manual for the toxicity assessment of traditional herbal medicines. Nat. Prod. Commun.2016; 11, 1763-1773.

10. Tumisem and E. Puspawiningtiyas. Kadar Logam dan Cara Mudah Mengenali Udang yang Terakumulasi Logam: Studi Kasus tentang Udang di Sungai Donan Cilacap, Jawa Tengah. J. Mns. dan Lingkung. 2011; 18, 114-126.

11. U. Saleem, S. Amin, B. Ahmad, H. Azeem, F. Anwar, and S. Mary. "Acute oral toxicity evaluation of aqueous ethanolic extract of Saccharum munja Roxb. roots in albino mice as per OECD $425 \mathrm{TG}$. Toxicol. Reports. 2017; 4, 580-585.

12. OECD/OECDE. "Guidelines for the Testing of Chemicals: Acute Oral Toxicity - Up-and-Down-Procedure (UDP). 2008; 1-27.

13. S. Sindhu and P. M. Sherief. Extraction, Characterization, Antioxidant and AntiInflammatory Properties of Carotenoids from the Shell Waste of Arabian Red Shrimp Aristeus alcocki , Ramadan 1938. Open Conf. Proc. J. 2011; 2, 95-103.

14. P. Panicha, N. Supatra, and P. Itthayakorn. Antimicrobial Activities of Vegetable OilExtracted Astaxanthin From Microalgae Haematococcus pluvialis. 1st Mae Fah Luang Univ. Int. Conf. 2012; 1-8.

15. T. Sutrisno, E. Asni, M. Zulkifli, and Ismawati. Histopatologi aorta torasika tikus putih (Rattus norvegicus strain wistar) Jantan setelah pemberian diet aterogenik selama 12 minggu. Jom FK. 2014; 2, 1-14.

16. T. E. Hamm, A. King-Herbert, and M. A. Vasbinder. "Chapter 27 - Toxicology," in The Laboratory Rat. 2006; 803-816.

17. A. B. Sutjiatmo, E. Y. Sukandar, Candra, and S. N. Vikasari. "Uji toksisitas akut ekstrak air herba pecut kuda (Stachytarpheta jamaicensis L. Vahl) pada mencit Swiss Webster. J. Ilm. Farm. 2015; 3, 37-42.

18. G. N. Teke and V. Kuete. Acute and Subacute Toxicities of African Medicinal Plants. Elsevier Inc. 2014; 63-98.

19. T. Katsumata, T. Ishibashi, and D. Kyle. A sub-chronic toxicity evaluation of a natural astaxanthin-rich carotenoid extract of Paracoccus carotinifaciens in rats. Toxicol. Reports. 2014; 1, 582-588.

20. T. Niu et al. Safety assessment of astaxanthin from Haematococcus pluvialis: Acute toxicity, genotoxicity, distribution and repeat-dose toxicity studies in gestation mice. Regul. Toxicol. Pharmacol. 2020; 115. 